Article

\title{
A Systematic Approach to Calculate Unit Emergy Values of Cement Manufacturing in China Using Consumption Quota of Dry and Wet Raw Materials
}

\author{
Junxue Zhang ${ }^{1, *}$, Ravi S. Srinivasan ${ }^{2, *}$ and Changhai Peng ${ }^{1,3, *}$ \\ 1 School of Architecture, Southeast University, Nanjing 210096, China \\ 2 Urban Building Energy, Sensing, Controls, Big Data Analysis and Visualization (UrbSys) Laboratory, M.E. \\ Rinker, Sr. School of Building Construction, College of Design, Construction and Planning, \\ University of Florida, Gainesville, FL 32611, USA \\ 3 Key Laboratory of Urban and Architectural Heritage Conservation, Ministry of Education, \\ Nanjing 210096, China \\ * Correspondence: zhangjunxue2017@foxmail.com (J.Z.); sravi@ufl.edu (R.S.S.); \\ pengchanghai@seu.edu.cn (C.P.)
}

Received: 12 May 2020; Accepted: 4 July 2020; Published: 13 July 2020

check for updates

\begin{abstract}
The Chinese cement industry produced 2150 million metric tons of cement in 2014, accounting for $58.1 \%$ of the world's total. This industry has a hugely destructive effect on the environment owing to its pollution. The environmental impact of cement manufacturing is a major concern for China. Although researchers have attempted to estimate impacts using life cycle assessment approaches, it lacks the ability to provide a holistic evaluation of the impacts on the environment. Emergy analysis, through ecological accounting, offers environmental decision making using elaborate book keeping. In spite of the high environmental impact of the cement industry, there has only been a handful of research work done to compute the unit emergy values (UEVs) of cement manufacturing in China. A thorough study of existing UEVs of cement manufacturing in China showed pitfalls that may lead to inaccurate estimations if used in emergy analysis. There is a strong need for a new, updated UEV for cement manufacturing in China, particularly reflecting both the dry and wet raw materials in the manufacturing process. This paper develops a methodology to calculate the nonrenewable resources used in cement manufacturing, particularly using mainstream cement production line. Our systematic approach-based UEV estimates of cement manufacturing in China using the quota method are $2.56 \times 10^{12} \mathrm{sej} / \mathrm{kg}$ (wet material) and $2.46 \times 10^{12} \mathrm{sej} / \mathrm{kg}$ (dry material). Emergy indicators such as environmental loading ratios which were calculated at 2390 (wet material) and 2300 (dry material); emergy yield ratios at 15.7 and 15.8; and emergy sustainability indices at 0.0066 and 0.0069 for dry and wet materials used in cement manufacturing, respectively; these show the immense impact on the environment in China.
\end{abstract}

Keywords: emergy analysis; unit emergy values; quota method; cement manufacturing; China

\section{Introduction}

More often than not, researchers have embarked on the environmental accounting of buildings using life cycle assessments (LCAs) that focus on the impact of emissions and resource consumption. Cátia et al. (2019) assessed the environmental influence of the prefabricated concrete elements for buildings based on the LCA method [1]; Marcella et al. (2020) discussed whole building LCAs and the associated environmental impacts [2]; Mohammad et al. (2019) used the LCA approach to estimate the environmental impacts of conventional construction approaches [3]; Yang et al. (2019) carried out the LCA method to evaluate the building construction sector in China to calculate the energy consumption 
and related carbon emissions [4]; and Michele et al. (2019) implemented the LCA methodology on building in Brazil for the assessment of its environmental impact [5]. These environmental impact studies focused on the impact on air, water, and land and did not include the impact on ecology.

However, another comprehensive evaluation approach is ecological accounting, e.g., emergy analysis which offers environmental decision-making solutions using elaborate bookkeeping. The emergy theory, founded by H. T. Odum, originated in ecology and has been applied in several fields including those of agriculture [6], urban buildings [7], built environments [8], industry [9] and natural landscapes [10], whereas Srinivasan et al., 2014 compared the ecological accounting model (emergy analysis) with LCAs, which mainly focuses on the full-service life of the building, including the building material, construction, use, and the end of life [11].

The emergy method is an effective tool for qualitative and quantitative analysis. By measuring the energy efficiency of different systems, the assessments can derive the economic benefits and competitiveness of the system [12] and reflect the level of development of specific systems for sustainability [13]. Emergy is used to conduct a comprehensive analysis and evaluation of the system's energy flow, currency flow, population flow, and information flow.

The core of emergy is solar energy [14]. All resources and energy are derived from the sun, so the value can be used to evaluate the sustainability of products, services, systems, and the economy. It can unify resources, energy, and services into one platform to calculate and compare $[15,16]$. Emergy, therefore, is defined as the available solar energy directly or indirectly used to be provided to a product or to provide a service. The unit of emergy is solar emjoule (sej). Solar transformity represents the solar emergy to produce one unit of available energy of a product and service, and the unit is solar emjoules per joule (sej/j). Solar transformities have three major unit emergy intensity values, including transformity, specific emergy, and emergy per unit money [14]. Specific emergy is the emergy amount per unit mass of material (sej/kg). Emergy per unit money connects the monetary benefit and emergy value. Unit emergy values (UEVs) explain the emergy value of one unit of mass, energy, service, or money. UEVs are the efficiency of the evaluated system. The emergy accounting process usually consists of four steps, namely, Step 1: establishing a system diagram; Step 2: constructing an emergy value inventory table; Step 3: calculating the ratio and emergy index; and Step 4: the in-depth analysis and policy discussions. The basic calculation formulas of emergy can be shown as three equations:

$$
\begin{aligned}
& \mathrm{U}(\text { sej })=\mathrm{N}(\mathrm{J}) \times \mathrm{UEV}(\text { sej } / \mathrm{j}) \\
& \mathrm{U}(\text { sej })=\mathrm{M}(\mathrm{g}) \times \mathrm{UEV}(\text { sej } / \mathrm{g}) \\
& \mathrm{U}(\text { sej })=\mathrm{V}(\$) \times \mathrm{UEV}(\text { sej } / \$)
\end{aligned}
$$

where $\mathrm{U}$ is the emergy; N, M, V represent the unit of Joule (J), grams (g), and money (\$), respectively. Emergy indicators, listed below, can be used to evaluate the system with respect to the environment. These indicators, in other words, may be synonymous to mid-point indicators in a LCA study.

(1) Renewability rate ( $R \%)$ : it is a ratio between the renewable element and the total element. A higher renewability rate means a better ecological level.

(2) Non-renewability rate of the local resource ( $\mathrm{N} \%)$ displays the ratio within the local resource emergy and total emergy. Higher N\% demonstrates worse ecological degrees.

(3) Emergy yield ratio (EYR): EYR can be computed in the light of the total emergy section and imported emergy section, which shows an ability that can generate emergy. The higher the EYR is, the better the consequent of the cement plant is. The higher input of purchased emergy could bring about the lower EYR, revealing the competitive ability of the evaluated cement plant.

(4) Environmental loading ratio (ELR): as the ratio of the non-renewable emergy and purchased emergy to the renewable emergy, the EIR is defined, which can be used to elaborate the ecological load of the evaluated ecosystem, including a non-resource emergy pressure, purchased emergy pressure and others. 
(5) Emergy sustainability index (ESI): ESI demonstrates the ratio between the EYR and the ELR. It expresses the comprehensive effect of the environment and economy for the evaluated system.

\subsection{Emergy Analysis of Construction of Buildings and Pavements in China}

The application of emergy analysis in the field of building construction has been practiced in the U.S. For example, Srinivasan et al. (2015) discussed the renewable substitutability index or RSI [17], to identify and improve renewable resource usage in building based on solar emergy and the renewable emergy balance or REB [8]. A thorough comparison of LCA tools and emergy analysis was conducted by Srinivasan et al. (2014) [11] which was concluded with a detailed discussion of the advantages and disadvantages of existing tools. By integrating the energy method and emergy approach, a comprehensive methodology was developed by Hwang et al. to study the optimal building form [18]. Hwang et al. (2017) [19] also utilized a series of indices to evaluate the sustainability of a net-zero energy building based on the global environmental perspective. To have the entire demonstration of building sustainability, Hwang et al. (2017) attempted to integrate the emergy method and information metrics and simulate the environment of the building model [20,21]. A thorough review of the existing literature by the authors showed that there is only one article that focused on the emergy analysis of building construction in China, Table 1. Similarly, there is only one emergy study related to cement pavement that was conducted in China [22].

Table 1. Emergy analysis of building construction in China.

\begin{tabular}{|c|c|c|c|c|}
\hline Author, Year & Building Type & & Remarks & \\
\hline \multirow{6}{*}{$\begin{array}{l}\text { Dezhi et al., } \\
2011 \text { [23] }\end{array}$} & \multirow{6}{*}{$\begin{array}{l}\text { Six residential } \\
\text { buildings }\end{array}$} & 1 & Concrete building, 5 storeys, $3225 \mathrm{~m}^{2}$ & \multirow{3}{*}{ Beijing city } \\
\hline & & 2 & Concrete building, 12 storeys, $9903.44 \mathrm{~m}^{2}$ & \\
\hline & & 3 & Concrete building, 21 storeys, $0.59 \mathrm{~m}^{2}$ & \\
\hline & & 4 & Concrete building, 4 storeys, $2017.21 \mathrm{~m}^{2}$ & \multirow{3}{*}{ Shanghai city } \\
\hline & & 5 & Concrete building, 11 storeys, $5011.95 \mathrm{~m}^{2}$ & \\
\hline & & 6 & Concrete building, 15 storeys, $7435.88 \mathrm{~m}^{2}$ & \\
\hline
\end{tabular}

In China, the cement industry produced 2330 million metric tons of cement in 2019, accounting for more than $51.4 \%$ of the world's total [24]. Needless to say, as a heavy industry with serious pollution, the cement industry has a hugely destructive effect on the environment.

For example, due to the huge nonrenewable resource consumption in the manufacturing of cement, there are 15.5 million tons of sulfur dioxide $\left(\mathrm{SO}_{2}\right), 11.8$ million tons of nitrogen oxides (NOx), and 15.3 million tons of particulates [25]. In addition to exhaust gases, industrial wastewater and solid wastes are also the major pollutants, which are 22.23 million tons and 39.76 million tons, respectively [25].

In spite of the high resource input and the high pollution emission of the cement industry, there is only a handful of research work done to compute the UEVs of cement manufacturing in China; they are: Wei et al. (2016) [26], who studied the life cycle emergy assessment of China's cement industry and Xiao et al. (2017) [27], who conducted a sustainable assessment of China's cement industry in 2010 based on emergy, and the results show that the proportion of fossil fuels is enormous, and such consumption cannot be sustained.

\subsection{A Need for an Updated UEV for Cement Manufacturing in China}

As discussed previously, there are only a handful of studies that have focused on the UEVs of cement manufacturing in China [26,27]. Table 2 lists these three research works by source data, emergy baseline used, raw materials, and their respective UEVs. It is to be noted that while Wei et al. (2016) used the 2015 data of one cement plant in China [26], Xiao et al. (2017) used the 2010 data that relate to the entire cement manufacturing in China. It is to be noted that although Song and Chen's (2016) work does not explicitly calculate the UEV of cement manufacturing [28], their work is added to Table 2. 
Although these were the first ever UEVs calculated for cement manufacturing, they may not adequately reflect owing to the following, Table 2 .

\subsection{Primary vs. Secondary Raw Materials in Cement Manufacturing}

At present, there are no UEV calculations by researchers using cement production based on primary raw material proportions, of raw materials such as $\mathrm{SiO}_{2}, \mathrm{Al}_{2} \mathrm{O}_{3}, \mathrm{Fe}_{2} \mathrm{O}_{3}, \mathrm{CaO}, \mathrm{MgO}$, and $\mathrm{SO}_{3}$. These primary raw materials are used in specific proportions to form secondary raw materials such as limestone, gypsum, slag, clay, and sulfuric acid residue, which are used in cement manufacturing. For example, limestone (secondary raw material) is a mix of $\mathrm{SiO}_{2}, \mathrm{Al}_{2} \mathrm{O}_{3}, \mathrm{Fe}_{2} \mathrm{O}_{3}, \mathrm{CaO}, \mathrm{MgO}$, and $\mathrm{SO}_{3}$ (primary raw materials). Cement manufacturing industries provide the quantities of primary raw materials; the quantities of secondary raw materials used in cement manufacturing are, in most cases, classified to maintain the secrecy of their product. That said, it is critical to calculate and validate the quantities of secondary raw materials, which will then be used in the calculation of the UEV of cement. Moreover, as shown in Table 2, some of the secondary raw materials used in cement manufacturing were left out; for example, while clay is not used in Wei et al. (2016), limestone, pyrite cinder, and fly ash were left out in Xiao et al. (2017). It is vital to include all the raw materials used in the calculation of UEV as each of these contribute to the overall emergy of the final product.

Dry vs. wet secondary raw materials: cement manufacturing may use either dry or wet raw materials based on the water content. This classification, i.e., dry or wet, affects the overall energy used in the manufacturing of cement. The UEVs listed in Table 2, unfortunately, do not provide the specifics related to water content, i.e., dry or wet.

\subsection{Emergy Baseline}

The most updated, current emergy baseline is $12.0 \times 10^{24} \mathrm{sej} / \mathrm{yr}$ per Brown et al. (2016) [29]. Among the three UEVs listed in Table 2, only Wei et al. (2016) used this current emergy baseline.

There is a strong need for a new, updated UEV for cement manufacturing in China, particularly reflecting both dry and wet raw materials in the manufacturing process. This paper develops a methodology to calculate the nonrenewable resources used in cement manufacturing. For the purposes of this study, the geo-biosphere emergy baseline uses the latest standards of $12.0 \times 10^{24} \mathrm{sej} / \mathrm{yr}$ [29]. This paper is organized as follows: Section 2 discusses the emergy analysis of dry and wet cement manufacturing in China; this section comprises two sub-sections, namely the emergy flow diagram (Section 2.1) and the data quantity calculation and sources (Section 2.2). Section 2.2 elaborates on the individual components of the emergy analysis table, i.e., renewable resources (Section 2.2.1), nonrenewable resources (Section 2.2.2), energy (Section 2.2.3), transport (Section 2.2.4), and labor and service (Section 2.2.5). As noted earlier, the crux of this paper is the development of a methodology to systematically calculate the secondary raw materials (dry and wet) used in cement manufacturing in China, given that only the primary raw material data are provided by a manufacturing facility. That said, the nonrenewable resources section is further divided into sub-sections to reflect Step 1: identify the composition of the primary raw materials used in the preparation of secondary raw materials (Figure 3 step 1), Step 2: calculate the proportion of secondary raw materials used in cement manufacturing (Figure 3 step 2), Step 3: validate the calculated proportion of secondary raw materials using theoretical target values for cement (Figure 3 step 3), Steps 4A and 4B: calculate the consumption quota of dry and wet raw materials (Figure 3 step 4A and 4B), and Step 5: calculate the consumption quota of water. The results and discussions (Section 3) are elaborated in two sub-sections, namely, Emergy Analysis Table (Section 3.1) and Emergy Indicators (Section 3.2), which are followed by conclusions (Section 4). 
Table 2. Comparison of the unit emergy values (UEVs) of cement manufacturing in China.

\begin{tabular}{|c|c|c|c|c|c|c|c|c|c|c|}
\hline \multirow{2}{*}{ Author } & \multirow{2}{*}{$\begin{array}{l}\text { Basic Data } \\
\text { Source }\end{array}$} & \multirow{2}{*}{$\begin{array}{c}\text { Emergy Baseline } \\
\text { (Sej/yr) }\end{array}$} & \multicolumn{7}{|c|}{ Raw materials } & \multirow{2}{*}{$\begin{array}{l}\text { UEVs of Cement } \\
(\text { Sej/kg) }\end{array}$} \\
\hline & & & Limestone & Gypsum & Sandstone & Clay & Pyrite Cinder & Water & Fly Ash & \\
\hline Wei et al., 2016 [26] & $\begin{array}{l}\text { One cement } \\
\text { plant }\end{array}$ & $12.0 \times 10^{24}$ & $\nabla$ & $\nabla$ & $\nabla$ & $x$ & $\nabla$ & $\nabla$ & $\nabla$ & $1.93 \times 10^{12}$ \\
\hline Xiao et al., 2017 [27] & $\begin{array}{c}\text { The entire data } \\
\text { of } 2010\end{array}$ & $15.83 \times 10^{24}$ & $x$ & $\nabla$ & $\nabla$ & $\nabla$ & $x$ & $\nabla$ & $\times$ & $3.64 \times 10^{12}$ \\
\hline $\begin{array}{l}\text { Song and Chen, } \\
2016[28]\end{array}$ & $\begin{array}{l}\text { One cement } \\
\text { plant }\end{array}$ & $15.83 \times 10^{24}$ & $\nabla$ & $\nabla$ & $\nabla$ & $x$ & $\nabla$ & $x$ & $\nabla$ & $3.05 \times 10^{12}$ \\
\hline
\end{tabular}




\section{Emergy Analysis of Cement Manufacturing in China Using Dry and Wet Raw Materials}

The cement manufacturing process is shown in Figure 1. The process includes the raw material system, the sintering process, grinding process, and finally, the packaging process. The main equipment are the cooling equipment, rotary kiln, preheater, and the decomposition furnace.

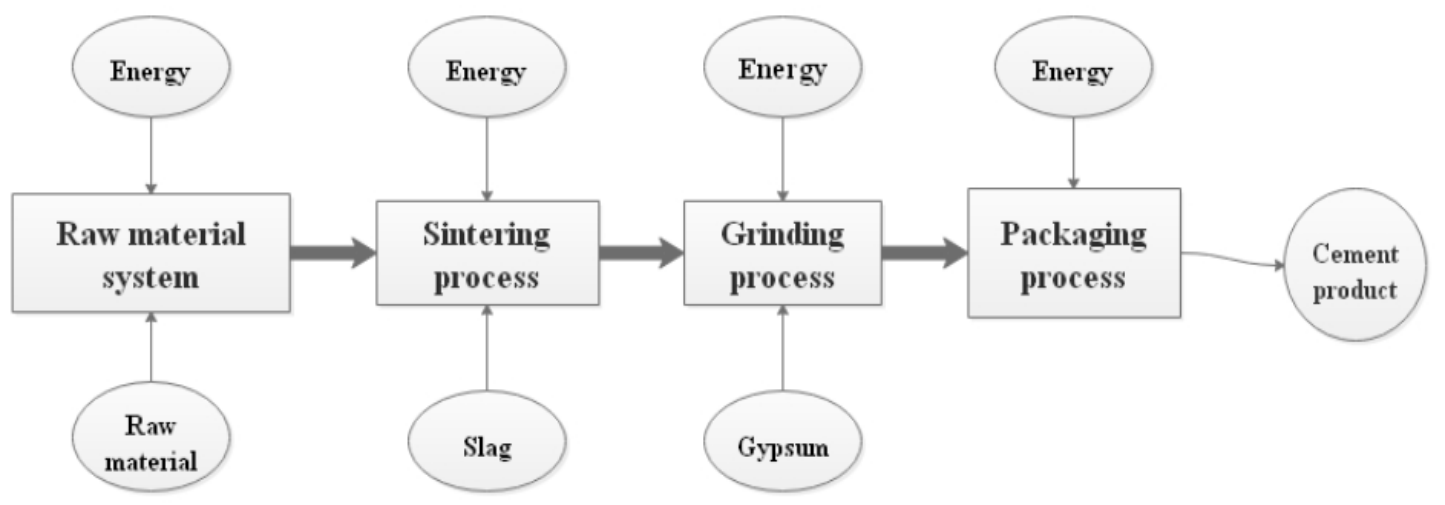

Figure 1. Core steps of the cement manufacturing process.

At present, there are several different cement production lines in China. However, for this paper, we obtained the data related to primary raw materials from one of the largest cement manufacturing industries. At this facility, on a typical day, 5000 tons of cement is manufactured.

\subsection{Emergy Flow Diagram of Cement Manufacturing}

Drawing emergy flow diagrams can help understand and analyze the emergy flow system of a specific object. Emergy is used in four main processes of cement manufacturing, namely the ingredient process, sintering process, grinding process, and packaging process. The relationship between the specific process of cement and emergy is shown in Figure 2.

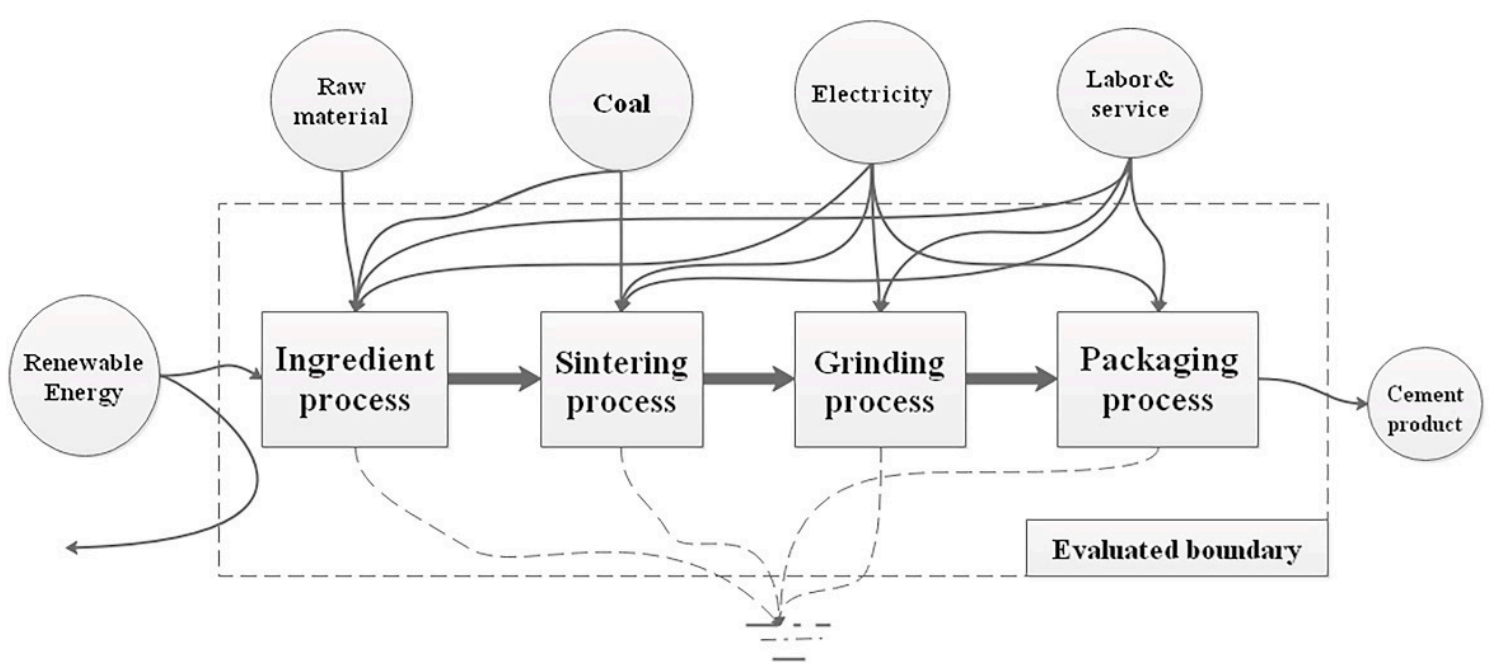

Figure 2. Cement product emergy diagram.

\subsection{Data Quantity Calculation and Sources}

The emergy analysis shown below follows the sequence as discussed in the emergy theory, i.e., renewable resources (Section 2.2.1), nonrenewable resources (Section 2.2.2), energy (Section 2.2.3), and labor and service (Section 2.2.4). It is to be noted that truck transportation is not included in the emergy analysis owing to a lack of data. 


\subsubsection{Renewable Resources}

All the UEVs were selected according to the latest baseline of $12.00 \times 10^{24} \mathrm{sej} / \mathrm{yr}$ [29].

(1) Solar energy calculation:

Area of cement plant $=13,424 \mathrm{~m}^{2}$ (collected data);

Insolation (Jiangsu Province, China) $=5.00 \times 10^{9}-5.85 \times 10^{9} \mathrm{~J} / \mathrm{m}^{2} / \mathrm{yr}[30]$;

Albedo = $0.30[30]$;

Energy $=($ insolation $) \times(1$-albedo $) \times($ area $)=\left(5.43 \times 10^{9} \mathrm{~J} / \mathrm{m}^{2} / \mathrm{yr}\right) \times(1-0.30) \times\left(13,424 \mathrm{~m}^{2}\right)=$ $5.10 \times 10^{13} \mathrm{~J} / \mathrm{yr}$;

$\mathrm{UEV}=1.00 \mathrm{sej} / \mathrm{j}$ by definition [14];

Emergy of one year $=5.10 \times 10^{13} \mathrm{~J} / \mathrm{yr} \times 1 \mathrm{yr} \times 1.00 \mathrm{sej} / \mathrm{j}=5.10 \times 10^{13} \mathrm{sej}$;

Emergy of one day $=5.10 \times 10^{13} \mathrm{sej} / 365=1.39 \times 10^{11} \mathrm{sej}$.

(2) Rain (geopotential energy) calculation:

Area of cement plant $=13,424 \mathrm{~m}^{2}$ (collected data);

Rainfall (annual average, $n=5)=0.68 \mathrm{~m} / \mathrm{yr}$ [31];

Average elevation $=316 \mathrm{~m}$; water density $=1000 \mathrm{~kg} / \mathrm{m}^{3} ;$ runoff rate $=40.00 \%[32,33]$;

Energy $=($ area $) \times($ rainfall $) \times($ runoff rate $) \times($ water density $) \times($ average elevation $) \times($ gravity $)=$ $\left(13,424 \mathrm{~m}^{2}\right) \times(0.68 \mathrm{~m} / \mathrm{yr}) \times(40 \%) \times\left(1000 \mathrm{~kg} / \mathrm{m}^{3}\right) \times(316 \mathrm{~m}) \times\left(9.8 \mathrm{~kg} / \mathrm{m}^{2}\right)=1.13 \times 10^{10} \mathrm{~J} / \mathrm{yr} ;$

$\mathrm{UEV}=1.31 \times 10^{4} \mathrm{sej} / \mathrm{j}[34]$;

Emergy of one year $=1.13 \times 10^{10} \mathrm{~J} / \mathrm{yr} \times 1 \mathrm{yr} \times 1.31 \times 10^{4} \mathrm{sej} / \mathrm{j}=1.48 \times 10^{14} \mathrm{sej}$;

Emergy of one day $=1.48 \times 10^{14} \mathrm{sej} / 365=4.09 \times 10^{11}$ sej.

(3) Rain (chemical potential energy) calculation:

Area of cement plant $=13,424 \mathrm{~m}^{2}$ (collected data);

Rainfall (annual average, $n=5$ ) $=0.68 \mathrm{~m} / \mathrm{yr}$;

Water density $=1000 \mathrm{~kg} / \mathrm{m}^{3}$;

Evapotranspiration rate $=60 \%[32,33]$;

Gibbs free energy of water $=4940 \mathrm{~J} / \mathrm{kg}$;

Energy $=($ area $) \times($ rainfall $) \times($ evapotranspiration rate $) \times($ water density $) \times($ Gibbs free energy of water $)=\left(13,424 \mathrm{~m}^{2}\right) \times(0.68 \mathrm{~m} / \mathrm{yr}) \times\left(1000 \mathrm{~kg} / \mathrm{m}^{3}\right) \times(60 \%) \times(4.40 \mathrm{~J} / \mathrm{kg})=2.71 \times 10^{10} \mathrm{~J} / \mathrm{yr}$;

$\mathrm{UEV}=2.35 \times 10^{4} \mathrm{sej} / \mathrm{j}[35]$;

Emergy of one year $=2.71 \times 10^{10} \mathrm{~J} / \mathrm{yr} \times 1 \mathrm{yr} \times 2.35 \times 10^{4} \mathrm{sej} / \mathrm{j}=6.37 \times 10^{14} \mathrm{sej}$;

Emergy of one day $=6.37 \times 10^{14} \mathrm{sej} / 365=1.75 \times 10^{11}$ sej.

(4) Wind energy calculation:

Area of cement plant $=13,424 \mathrm{~m}^{2}$ (collected data);

Air density $=1.29 \mathrm{~kg} / \mathrm{m}^{3}$;

Wind velocity (annual average, $n=2)=1.95 \mathrm{~m} / \mathrm{s}$ [35];

Velocity of geostrophic wind $=3.25 \mathrm{~m} / \mathrm{s}$ (surface winds are considered as 0.6 of geostrophic wind [35];

Drag coefficient $=0.001[36,37]$;

Energy $=($ area $) \times($ air density $) \times($ drag coefficient $) \times(\text { velocity of geostrophic wind })^{3}=\left(13,424 \mathrm{~m}^{2}\right)$ $\times\left(1.29 \mathrm{~kg} / \mathrm{m}^{3}\right) \times 0.001 \times(3.25 \mathrm{~m} / \mathrm{s})^{3} \times\left(3.15 \times 10^{7} \mathrm{~s} / \mathrm{yr}\right)=1.77 \times 10^{9} \mathrm{~J} / \mathrm{yr}$;

$\mathrm{UEV}=1.90 \times 10^{3} \mathrm{sej} / \mathrm{j}[14]$;

Emergy of one year $=1.77 \times 10^{9} \mathrm{~J} / \mathrm{yr} \times 1 \mathrm{yr} \times 1.90 \times 10^{3} \mathrm{sej} / \mathrm{j}=3.36 \times 10^{12} \mathrm{sej}$;

Emergy of one day $=3.36 \times 10^{12} \mathrm{sej} / 365=9.21 \times 10^{9} \mathrm{sej}$. 
(5) Geothermal heat calculation:

Area of cement plant $=13,424 \mathrm{~m}^{2}$ (collected data);

Heat flow (average $)=0.035 \mathrm{~J} / \mathrm{m}^{2} / \mathrm{s}$. Energy $=($ area $) \times($ heat flow $)=\left(13,424 \mathrm{~m}^{2}\right) \times\left(0.035 \mathrm{~J} / \mathrm{m}^{2} / \mathrm{s}\right) \times$ $\left(3.15 \times 10^{7} \mathrm{~s} / \mathrm{yr}\right)=1.48 \times 10^{10} \mathrm{~J} / \mathrm{yr} ;$

$\mathrm{UEV}=4.37 \times 10^{4} \mathrm{sej} / \mathrm{j}[38]$;

Emergy of one year $=1.48 \times 10^{10} \mathrm{~J} / \mathrm{yr} \times 1 \mathrm{yr} \times 4.37 \times 10^{4} \mathrm{sej} / \mathrm{j}=6.47 \times 10^{14} \mathrm{sej}$;

Emergy of one day $=6.47 \times 10^{14} \mathrm{sej} / 365=1.77 \times 10^{11} \mathrm{sej}$.

\subsubsection{Nonrenewable Resources}

A. Consumption Quota of Dry and Wet Secondary Raw Materials Used in Cement Manufacturing

Previous studies $[26,27]$ used the data related to secondary raw materials directly to calculate UEVs. However, as previously stated, the manufacturing facilities maintain a log of primary raw materials (e.g., $\mathrm{SiO}_{2}, \mathrm{Al}_{2} \mathrm{O}_{3}, \mathrm{Fe}_{2} \mathrm{O}_{3}, \mathrm{CaO}, \mathrm{MgO}, \mathrm{SO}_{3}$ ) rather than the secondary raw materials (e.g., limestone) used in cement manufacturing. Besides, these facilities may use dry or wet raw materials for cement production. Hence, it is essential to calculate the consumption quota of dry and wet secondary raw materials to calculate UEVs. For this purpose, a systematic step-by-step approach was developed, see Figure 3. Using these six steps (1-3, 4A, 4B, and 5), the consumption quota of dry and wet secondary raw materials was calculated.

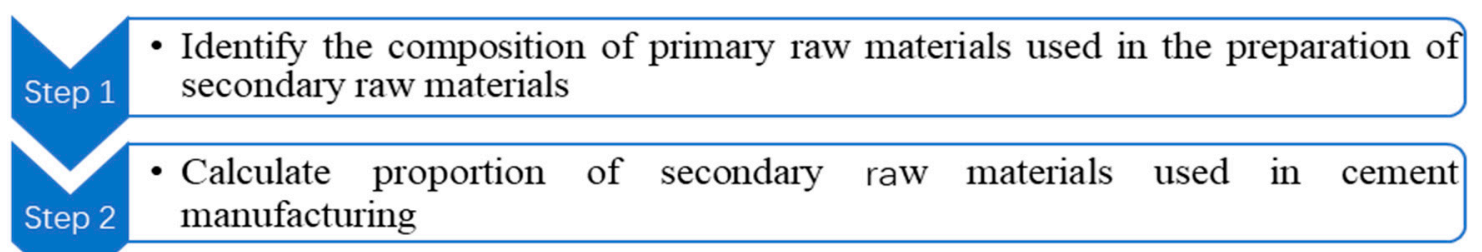

- Validate calculated proportion of secondary raw materials using theoretical
target values for cement

- Calculate consumption quota of dry raw materials (limestone, clay, sandstone, sulfuric acid residue), gypsum, and slag

- Calculate consumption quota of wet raw materials (limestone, clay, sandstone, Step 4B sulfuric acid residue), gypsum, and slag

Step 5

- Calculate consumption quota of water

Figure 3. The consumption quota calculated steps of the dry and wet secondary raw materials.

Step 1. Identify the composition of primary raw materials used in the preparation of secondary raw materials.

The production of standard cement [39] requires calcareous raw materials, clay raw materials, calibration raw materials, and auxiliary raw materials. China's cement energy consumption mainly uses coal and electricity. The details of the raw materials are shown in Tables 3-5. 
Table 3. Chemical composition of the secondary raw materials: limestone, clay, sandstone, sulfuric acid residue, and coal (\%).

\begin{tabular}{ccccccccc}
\hline \multirow{2}{*}{$\begin{array}{c}\text { Secondary Raw Materials } \\
\text { Used in Cement }\end{array}$} & \multicolumn{6}{c}{ Primary Raw Materials (Chemical Composition) } \\
\cline { 2 - 9 } & Loss & $\mathbf{S i O}_{\mathbf{2}}$ & $\mathbf{A l}_{\mathbf{2}} \mathbf{O}_{\mathbf{3}}$ & $\mathbf{F e}_{\mathbf{2}} \mathbf{O}_{\mathbf{3}}$ & $\mathbf{C a O}$ & $\mathbf{M g O}$ & $\mathbf{S O}_{\mathbf{3}}$ & $\Sigma$ \\
\hline Limestone & 41.98 & 3.20 & 0.52 & 0.11 & 53.10 & 0.53 & 0.05 & 99.62 \\
Clay & 13.37 & 31.42 & 33.21 & 15.16 & 0.48 & 1.13 & - & 94.95 \\
Sandstone & 3.53 & 83.83 & 8.66 & 1.65 & 0.15 & 0.16 & 0.02 & 99.60 \\
Sulfuric acid residue & 0.58 & 5.00 & 5.29 & 68.21 & 5.96 & 3.12 & 8.59 & 97.03 \\
\hline Note: baing
\end{tabular}

Note: basic data (of limestone clay, sandstone, and Sulfuric acid residue) came from Ref. [40-44].

Table 4. Chemical analysis of the secondary raw material gypsum (\%).

\begin{tabular}{|c|c|c|c|c|c|c|c|c|c|c|}
\hline $\begin{array}{l}\text { Secondary Raw } \\
\text { Materials Used } \\
\text { in Cement }\end{array}$ & Loss & $\mathrm{SiO}_{2}$ & $\mathrm{Fe}_{2} \mathrm{O}_{3}$ & $\mathrm{Al}_{2} \mathrm{O}_{3}$ & $\mathrm{CaO}$ & $\mathrm{MgO}$ & $\mathrm{K}_{2} \mathrm{O}$ & $\mathrm{Na}_{2} \mathrm{O}$ & $\mathrm{SO}_{3}$ & $\Sigma$ \\
\hline Gypsum & 9.12 & 16.75 & 0.97 & 4.85 & 25.12 & 1.02 & 0.88 & 0.50 & 39.64 & 99.80 \\
\hline
\end{tabular}

Table 5. The natural moisture of raw materials (\%).

\begin{tabular}{ccccccc}
\hline Limestone & Clay & Sandstone & Sulfuric Acid Residue & Coal & Gypsum & Slag \\
\hline 1.50 & 1.00 & 15.00 & 17.60 & 8.00 & 4.00 & 8.00 \\
\hline
\end{tabular}

Note: basic data (of limestone clay, sandstone, sulfuric acid residue, coal, gypsum and slag) came from Ref. [40-46].

Step 2. Calculate the proportion of secondary raw materials used in cement manufacturing.

The lime saturation coefficient, silicon rate, and aluminum rate are calculated and compared with theoretical values. For this purpose, according to the assumed raw material mix ratio [47], the clinker composition is calculated. If the calculation result does not meet the requirement, it is required to adjust the raw material ratio and calculate again until it fulfills the requirements. The raw material calculation results are shown in Tables 6 and 7.

Table 6. Raw material ratio calculation (unit: $100 \mathrm{~kg}$ ).

\begin{tabular}{cccccccccc}
\hline Raw Material & Proportion & Loss & $\mathrm{SiO}_{\mathbf{2}}$ & $\mathbf{A l}_{\mathbf{2}} \mathbf{O}_{3}$ & $\mathrm{Fe}_{\mathbf{2}} \mathbf{O}_{\mathbf{3}}$ & $\mathbf{C a O}$ & $\mathbf{M g O}$ & $\mathbf{S O}_{3}$ & $\Sigma$ \\
\hline Limestone & 0.82 & 35.12 & 2.75 & 0.47 & 0.09 & 44.23 & 0.51 & 0.07 & 83.24 \\
Clay & 0.05 & 0.56 & 1.31 & 1.33 & 0.62 & 0.02 & 0.06 & 0.00 & 3.90 \\
Sandstone & 0.12 & 0.42 & 9.63 & 0.98 & 0.19 & 0.03 & 0.03 & 0.00 & 11.28 \\
Sulfuric acid residue & 0.02 & 0.01 & 0.07 & 0.09 & 1.05 & 0.11 & 0.05 & 0.14 & 1.52 \\
Dry raw material & 1.00 & 36.11 & 13.76 & 2.87 & 1.95 & 44.39 & 0.65 & 0.21 & 99.94 \\
Raw material after & - & - & 21.53 & 4.49 & 3.05 & 69.47 & 1.02 & 0.33 & 99.89 \\
burning & & & & & & & & & \\
\hline
\end{tabular}

Table 7. The calculated value of the clinker composition.

\begin{tabular}{ccccccccc}
\hline Program & Proportion & $\mathbf{S i O}_{\mathbf{2}}$ & $\mathbf{A l}_{\mathbf{2}} \mathbf{O}_{\mathbf{3}}$ & $\mathbf{F e}_{\mathbf{2}} \mathbf{O}_{\mathbf{3}}$ & $\mathbf{C a O}$ & $\mathbf{M g O}$ & $\mathbf{S O}_{3}$ & $\Sigma$ \\
\hline Burning base material & $96.54 \%$ & 20.79 & 4.33 & 2.94 & 67.07 & 0.98 & 0.32 & 96.43 \\
Coal ash composition & $3.46 \%$ & 1.94 & 0.91 & 0.35 & 0.04 & 0.04 & 0.10 & 3.38 \\
Clinker composition & $100 \%$ & 22.64 & 5.24 & 3.29 & 67.11 & 1.02 & 0.42 & 99.81 \\
\hline
\end{tabular}


Incorporation of coal ash [48]:

$$
G_{A}=\frac{q A^{y} S}{Q^{y} \times 100}=\frac{2508 \times 28.8 \times 100}{\times 100}=3.46 \%
$$

where GA—goal ash of clinker, \%;

$\mathrm{q}$-heat consumption of clinker, $\mathrm{KJ} / \mathrm{Kg}$-cl;

unit heat consumption of clinker $=0.12 \times 20,900=2508 \mathrm{Kj} / \mathrm{Kg}$-cl;

$\mathrm{A}_{\mathrm{y}}$-ash of fuel air, \%;

s-coal ash sinking rate, $100 \%$;

$\mathrm{Q}_{\mathrm{y}}$-low calorific value of coal, 20,900 KJ/Kg.

Step 3. Validate the calculated proportion of secondary raw materials using theoretical target values for cement.

In this calculation, three theoretical standards can be used to verify the calculated proportion of secondary raw materials, which are lime saturation coefficient $(\mathrm{KH}=0.92 \pm 0.1)$, silicon rate $(\mathrm{SM}=2.6 \pm 0.1)$ and aluminum rate $(\mathrm{IM}=1.6 \pm 0.1)$, respectively [47].

Calculated values:

$$
\begin{gathered}
\mathrm{KH}=\frac{\mathrm{CaO}-1.65 \times A l 2 \mathrm{O} 3-0.35 \times F e 2 \mathrm{O} 3}{2.8 \mathrm{sio} 2}=\frac{65.15-1.65 \times 5.85-0.35 \times 3.48}{2.8 \times 23.68}=0.82 \\
S M=\frac{\mathrm{SiO} 2}{\mathrm{Fe} 2 \mathrm{O} 3+\mathrm{Al} 2 \mathrm{O} 3}=\frac{23.68}{3.48+5.85}=2.54 \\
I M=\frac{A l 2 \mathrm{O} 3}{\mathrm{Fe} 2 \mathrm{O} 3}=\frac{5.85}{3.48}=1.68
\end{gathered}
$$

The calculated ratio is close to the target value, so that the final ratio of raw materials is determined as Table 8:

Table 8. The ratio of the four main raw materials.

\begin{tabular}{cccc}
\hline Limestone & Clay & Sandstone & Sulfuric Acid Residue \\
\hline $82 \%$ & $5.0 \%$ & $12 \%$ & $2.0 \%$ \\
\hline
\end{tabular}

Step 4. A. Calculate the consumption quota of dry raw materials.

Taking $1 \mathrm{~g}$ cement clinker as an example, the total dry material can be calculated to obtain the calculated values, including limestone, clay, sandstone, and sulfuric acid slag. If $1 \mathrm{~g}$ cement needs to be calculated, other auxiliary materials such as standard coal, gypsum, and slag should be included.

Consumption quota of secondary raw materials (limestone, clay, sandstone, sulfuric acid residue)

Considering the amount of coal ash incorporation, the dry raw materials' theoretical consumption of $1 \mathrm{~g}$ cement clinker [47]:

$$
K_{1}=\frac{100-S}{100-I}=\frac{100-6.22}{100-36.11}=1.468 \mathrm{~g} / \mathrm{g}-\mathrm{cl}
$$

where $\mathrm{K}_{1}$-theoretical consumption of the dry raw material (g/g-cl);

I-Loss of dry raw material (\%);

$\mathrm{s}$-coal ash amount (\%). 
Considering the amount of coal ash incorporation, the dry raw materials consumption quota of $1 \mathrm{~g}$ clinker:

$$
K_{2}=\frac{100 K 1}{100-P}=\frac{100 \times 1.468}{100-3}=1.513 \mathrm{~g} / \mathrm{g}-\mathrm{cl}
$$

where $\mathrm{K}_{2}$-dry raw materials consumption quota (g/g-cl);

$\mathrm{P}$-loss of the dry raw materials (\%), Reasonable value is $3 \%$;

$$
\mathrm{K}_{\text {quota }}=\mathrm{K}_{2} \times \mathrm{A}
$$

where $\mathrm{K}_{\text {quota }}$-consumption quota of the dry raw materials (g/g-cl);

A-proportion of dry raw materials (\%).

Four dry raw material consumption quotas:

$$
\begin{aligned}
& \mathrm{K}_{\text {limestone }}=1.513 \times 0.82=1.241 \mathrm{~g} / \mathrm{g}-\mathrm{cl} ; \\
& \mathrm{K}_{\text {clay }}=1.513 \times 0.05=0.076 \mathrm{~g} / \mathrm{g}-\mathrm{cl} ; \\
& \mathrm{K}_{\text {sandstone }}=1.513 \times 0.12=0.182 \mathrm{~g} / \mathrm{g} \text {-cl; } \\
& \mathrm{K}_{\text {sulfuric acid residue }}=1.513 \times 0.02=0.030 \mathrm{~g} / \mathrm{g} \text {-cl } .
\end{aligned}
$$

The consumption quota of the wet material is displayed in Table 9.

Table 9. Consumption quota of the wet raw material.

\begin{tabular}{cccccc}
\hline Consumption Quota g/g-cl & Limestone & Clay & Sandstone & Sulfuric Acid Residue & $\Sigma$ \\
\hline & 1.260 & 0.077 & 0.214 & 0.033 & 1.584 \\
\hline
\end{tabular}

Gypsum consumption quota [49]:

$$
K_{d r y ~ g y p s u m}=\frac{100 d}{(100-d-e) \times(100-p)}=\frac{100 \times 5}{(100-5-4) \times(100-p)}=0.057 \frac{\mathrm{g}}{\mathrm{g}}-\mathrm{cl}
$$

where $\mathrm{K}_{\mathrm{dry}}$ gypsum - gypsum consumption quota $(\mathrm{g} / \mathrm{g}-\mathrm{cl})$;

$\mathrm{d}$, e-gypsum amount and mixed materials in cement (\%);

$p$-cement production loss (\%), value $=3 \%$.

Slag consumption quota (Chen, 2004):

$$
K_{\text {slag }}=\frac{100 e}{(100-d-e) \times(100-p)}=\frac{100 \times 4}{(100-5-4) \times(100-3)}=0.045 \mathrm{~g} / \mathrm{g}-\mathrm{cl}
$$

where $\mathrm{K}_{\text {slag }}$-slag consumption quota $(\mathrm{g} / \mathrm{g}-\mathrm{cl})$;

$\mathrm{d}$, e-slag amount and mixed materials in cement (\%);

$p$-Cement production loss (\%), value $=3 \%[46]$.

\section{B. Calculate Consumption Quota of Wet Raw Materials}

The consumption quota of secondary raw materials (limestone, clay, sandstone, and sulfuric acid residue).

In addition to the quota calculation of the dry materials, the quota of the wet materials can also be calculated based on the ratio of water content, Table 10. Through Equations (13)-(15) [50], the consumption quota of slag has been calculated, and the specific results are shown in Table 11.

$$
\text { Wet raw material }=\text { dry raw material } \times \frac{100}{100-\text { Moisture ratio }}
$$


Table 10. Wet raw material ratio.

\begin{tabular}{cccccc}
\hline Wet Raw Material & Limestone & Clay & Sandstone & Sulfuric Acid Residue & $\sum$ \\
\hline Proportion & 0.832 & 0.051 & 0.141 & 0.024 & 1.048 \\
Percentage & $79.4 \%$ & $4.9 \%$ & $13.5 \%$ & $2.2 \%$ & $100 \%$ \\
\hline
\end{tabular}

Table 11. Consumption quota of slag.

\begin{tabular}{cccccc}
\hline Cement & e $\%$ & d $\%$ & $\mathbf{P} \%$ & K Dry Slag $(\mathrm{g} / \mathrm{g}-\mathrm{cl})$ & Kwet Slag $(\mathrm{g} / \mathrm{g}-\mathrm{cl})$ \\
\hline Standard cement & 4 & 5 & 3 & 0.0453 & 0.0492 \\
\hline
\end{tabular}

Gypsum consumption quota:

$$
K_{\text {wet gypsum }}=K_{\text {dry gypsum }} \times \frac{100}{100-M}=0.059 \frac{\mathrm{g}}{\mathrm{g}}-\mathrm{cl}
$$

where $\mathrm{M}$ is the water ratio of gypsum (4\%).

Slag consumption quota:

$$
K_{\text {wet slag }}=K_{\text {slag }} \times \frac{100}{100-M}=0.12 \times \frac{100}{100-8}=0.049 \frac{\mathrm{g}}{\mathrm{g}}-\mathrm{cl}
$$

where $\mathrm{M}$ is the water ratio of slag $(8 \%)$.

Step 5. Calculate consumption quota of water.

The natural moisture of the raw materials is revealed in Table 12.

Table 12. The natural moisture of the raw materials (\%).

\begin{tabular}{ccccccc}
\hline Limestone & Clay & Sandstone & Sulfuric Acid Residue & Coal & Gypsum & Slag \\
\hline 1.50 & 1.00 & 15.00 & 17.60 & 8.00 & 4.00 & 8.00 \\
\hline
\end{tabular}

Note: basic data of (limestone clay, sandstone, sulfuric acid residue, coal, gypsum and slag) came from Ref. [40-46].

\subsubsection{Energy}

In this subsection, we calculate the energy used in the manufacture of cement. The calorific value of cement is $20,900 \mathrm{~kJ} / \mathrm{kg}$ based on the Chinese national standard. Table 13 illustrates the chemical composition of secondary raw materials, and Table 14 is the raw coal industry analysis.

Table 13. Chemical composition of the secondary raw materials: limestone, clay, sandstone, sulfuric

\begin{tabular}{|c|c|c|c|c|c|c|c|c|}
\hline \multirow{2}{*}{$\begin{array}{l}\text { Secondary Raw Material } \\
\text { Used in Cement }\end{array}$} & \multicolumn{8}{|c|}{ Primary Raw Materials (Chemical Composition) } \\
\hline & Loss & $\mathrm{SiO}_{2}$ & $\mathrm{Al}_{2} \mathrm{O}_{3}$ & $\mathrm{Fe}_{2} \mathrm{O}_{3}$ & $\mathrm{CaO}$ & $\mathrm{MgO}$ & $\mathrm{SO}_{3}$ & $\sum$ \\
\hline Coal & - & 56.12 & 26.40 & 10.00 & 1.12 & 1.19 & 3.02 & 98.25 \\
\hline
\end{tabular}
acid residue, coal (\%).

Table 14. Raw coal industry analysis (\%).

\begin{tabular}{ccccc}
\hline Name & Moisture & Ash & Volatile Ratio & Calorific Value \\
\hline coal & 1.10 & 25.30 & 8.80 & $20,900 \mathrm{~kJ} / \mathrm{kg}$ \\
\hline
\end{tabular}

Note: basic data of coal came from Ref. [44]. The basic data of the calorific value came from Ref. [51]. 
This paper utilizes the raw coal industry analysis as follows:

Standard coal used in the dry materials-based cement manufacturing:

$\mathrm{K}_{\text {coal }}=0.12 \mathrm{~g} / \mathrm{g}$-cl [52].

Standard coal used in the wet materials-based cement manufacturing [50]:

$$
K_{\text {wet coal }}=K_{\text {coal }} \times \frac{100}{100-M}=0.12 \times \frac{100}{100-8}=0.131 \mathrm{~g} / \mathrm{g}-\mathrm{cl}
$$

where $\mathrm{M}$ is the water ratio of coal $(8 \%)$.

\subsubsection{Electricity Used in Both Dry and Wet Materials-Based Cement Manufacturing}

Quota calculation of the $5000 \mathrm{t} / \mathrm{d}$ product line and the standard cement chemical composition has been shown in Appendix A.

This part is the actual scale calculation of the $5000 \mathrm{t} / \mathrm{d}$ production line, embracing the annual output of the cement clinker, the number of cement kiln calculation, and the production capacity of cement products. Following the $5000 \mathrm{t} / \mathrm{d}$ cement production line, the energy consumption standards were selected to compute the emergy of the whole cement production line.

The annual output of the cement Clinker

The production data are assumed to be as follows: production loss $=3 \%$; gypsum amount $=5 \%$; mixed material amount $=4 \%$. The design clinker production is $5000 \mathrm{t} / \mathrm{day}$, and the hourly output is $208.3 \mathrm{t} / \mathrm{h}$. The factual output of the clinker is $5500 \mathrm{t} /$ day, and the hourly output is $230 \mathrm{t} / \mathrm{h}$.

The daily production of clinker can be calculated as follows [49]:

$$
Q_{y}=\frac{100-d-e}{100-p} \times G_{y}=\frac{100-5-4}{100-5} \times 5500=5286 t / \text { day }
$$

where $\mathrm{Q}_{\mathrm{y}}$-required annual output of clinker $(\mathrm{t} / \mathrm{a})$;

$\mathrm{G}_{\mathrm{y}}$ - cement factory-scale (t/a);

$\mathrm{d}$-slag amount in cement (\%);

e-mixed materials in cement (\%);

$p$-cement production loss $(\%)$, value $=5 \%$.

The number of cement kiln can be calculated as follows [49]:

$$
n=\frac{Q_{y}}{8760 \times \beta \times Q_{h}}=\frac{5286 \times 360}{8760 \times 0.85 \times 230}=0.988 \approx 1
$$

where $n$-number of the pre-calciner kilns;

$\mathrm{Q}_{\mathrm{y}}$-required annual output of clinker $(\mathrm{t} / \mathrm{a})$;

$\mathrm{Q}_{\mathrm{h}}$ - production of selected kiln $(\mathrm{t} /(\mathrm{n} \cdot \mathrm{h}))$;

$\beta$-annual utilization rate of the kiln (0.85);

8760 - the number of hours throughout the year.

The production capacity of the $5000 \mathrm{t} / \mathrm{d}$ cement line can be calculated as follows [49]:

$$
\begin{gathered}
\mathrm{Q}_{\mathrm{h}}=n \mathrm{Q}_{\mathrm{h}}=1 \times 230=230(\mathrm{t} / \mathrm{h}) \\
\mathrm{Q}_{\mathrm{d}}=24 \mathrm{Q}_{\mathrm{h}}=230 \times 24=5500(\mathrm{t} / \mathrm{d})
\end{gathered}
$$

where $\mathrm{Q}_{\mathrm{h}}$-hourly output of clinker $(\mathrm{t} / \mathrm{h})$;

$\mathrm{Q}_{\mathrm{d}}$-daily output of clinker $(\mathrm{t} / \mathrm{d})$.

Manual quota and machine quota 
The main facilities of the entire cement production line comprise the limestone crusher, raw mill, rotary kiln, coal mill, dryer, cement mill, and the cement packaging machine. Based on the consumed electric power of all devices, the emergy of the machine quota can be computed. All the device types are shown in Table 15.

Table 15. Main equipment for the cement production process.

\begin{tabular}{ccccc}
\hline Name & Type & Production (t/h) & Number $(\boldsymbol{n})$ & $\begin{array}{c}\text { Running Time per } \\
\text { Week (h/w) }\end{array}$ \\
\hline Limestone crusher & TKLPC2022.F & 700 & 1 & 72 \\
Raw mill & TRM53.4 & 430 & 1 & 157 \\
Rotary kiln & \$4.8 $\times 72 \mathrm{~m}$ & 229.2 & 1 & 168 \\
Coal mill & HRM2200 & 45 & 1 & 168 \\
Dryer & $\varphi 2.4 \times 18 \mathrm{~m}$ & 24.4 & 2 & 157 \\
Cement mill & $\varphi 4.2 \times 13 \mathrm{~m}$ & 155 & 2 & 157 \\
Cement packaging machine & BX-8WY & 100 & 4 & 84 \\
\hline
\end{tabular}

\subsubsection{Labor and Service}

As the largest cement company in China, Anhui Conch Cement Company Limited has a qualified cement production line of $5500 \mathrm{t} / \mathrm{d}$. According to the annual report of the company, the manual quota is CNY 25.58/t.

Calculation standard $=$ CNY 25.58/t [31].

\section{Results and Discussions}

Table 16 contains the raw materials and energy required for a $5500 \mathrm{t} / \mathrm{d}$ cement production line in China. The raw material ratio is divided into a wet material ratio and a dry material ratio.

Table 16. Consumption quota calculation table of the raw materials (5000 t/d).

\begin{tabular}{|c|c|c|c|c|c|c|}
\hline \multirow{3}{*}{ Name } & \multirow{3}{*}{$\begin{array}{l}\text { Moisture } \\
\quad(\%)\end{array}$} & \multirow{3}{*}{$\begin{array}{l}\text { Loss } \\
(\%)\end{array}$} & \multirow{2}{*}{\multicolumn{2}{|c|}{$\begin{array}{c}\text { Consumption Quota } \\
\text { (g/g-cl) }\end{array}$}} & \multicolumn{2}{|c|}{ Material Calculation Table (t) } \\
\hline & & & & & \multirow{2}{*}{$\begin{array}{c}\text { Dry Material } \\
\text { Day }\end{array}$} & \multirow{2}{*}{$\begin{array}{c}\text { Wet Material } \\
\text { Day }\end{array}$} \\
\hline & & & Dry Material & Wet Material & & \\
\hline Limestone & 1.50 & - & 1.241 & 1.26 & 3681.49 & 3583.25 \\
\hline Clay & 1.00 & - & 0.076 & 0.077 & 225.46 & 218.98 \\
\hline Sandstone & 15.00 & - & 0.182 & 0.214 & 539.91 & 608.58 \\
\hline $\begin{array}{l}\text { Sulfuric acid } \\
\text { residue }\end{array}$ & 17.60 & - & 0.03 & 0.033 & 88.99 & 93.847 \\
\hline $\begin{array}{c}\text { Raw } \\
\text { material }\end{array}$ & - & 3.00 & 1.529 & 1.584 & 4535.87 & 4504.65 \\
\hline Gypsum & 4.00 & 3.00 & 0.057 & 0.059 & 169.09 & 167.79 \\
\hline Slag & 8.00 & 3.00 & 0.045 & 0.049 & 133.49 & 139.35 \\
\hline Coal & 8.00 & 3.00 & 0.12 & 0.131 & 660 & 720.5 \\
\hline $\begin{array}{l}\text { Standard } \\
\text { cement }\end{array}$ & - & - & - & - & 5500 & 5500 \\
\hline Electricity & - & - & $88 \mathrm{kV}$ & $/ \mathrm{t}$ [52] & $4.84 \times 10^{5} \mathrm{kWh}$ & $4.84 \times 10^{5} \mathrm{kWh}$ \\
\hline
\end{tabular}

\subsection{UEVs' Calculation of a Whole Cement Production Line of $5500 \mathrm{t} / \mathrm{d}$}

Through the above calculation of the raw material quota, energy quota, and the manual quota, and equipment quota, the emergy calculations of the $5500 \mathrm{t} / \mathrm{d}$ production line were completed. The specific calculation process is shown in Tables 17-19. The final calculated UEVs are $2.56 \times 10^{12} \mathrm{sej} / \mathrm{kg}$ (wet material) and $2.46 \times 10^{12} \mathrm{sej} / \mathrm{kg}$ (dry material). 
Table 17. Emergy calculation of the cement products based on nonrenewable resources.

\begin{tabular}{ccccccc}
\hline Item & $\begin{array}{c}\text { Wet Material } \\
\text { Quantity }\end{array}$ & $\begin{array}{c}\text { Dry Material } \\
\text { Quantity }\end{array}$ & $\begin{array}{c}\text { UEVs } \\
\text { (sej/unit) }\end{array}$ & Ref. & $\begin{array}{c}\text { Wet Material Emergy } \\
\text { (sej) }\end{array}$ & $\begin{array}{c}\text { Dry Material Emergy } \\
\text { (sej) }\end{array}$ \\
\hline Limestone & $1260 \mathrm{~kg}$ & $1241 \mathrm{~kg}$ & $1.27 \times 10^{12}$ & {$[12]$} & $1.60 \times 10^{15}$ & $1.58 \times 10^{15}$ \\
Clay & $77 \mathrm{~kg}$ & $76 \mathrm{~kg}$ & $1.27 \times 10^{12}$ & {$[12]$} & $9.78 \times 10^{13}$ & $9.65 \times 10^{13}$ \\
Sandstone & $214 \mathrm{~kg}$ & $182 \mathrm{~kg}$ & $1.42 \times 10^{12}$ & {$[14]$} & $3.04 \times 10^{14}$ & $2.58 \times 10^{14}$ \\
Slag & $49 \mathrm{~kg}$ & $48 \mathrm{~kg}$ & $1.68 \times 10^{12}$ & {$[12]$} & $5.49 \times 10^{13}$ & $5.38 \times 10^{13}$ \\
Gypsum & $59 \mathrm{~kg}$ & $57 \mathrm{~kg}$ & $1.27 \times 10^{12}$ & {$[12]$} & $7.49 \times 10^{13}$ & $7.24 \times 10^{13}$ \\
Sulfuric acid residue & $33 \mathrm{~kg}$ & $30 \mathrm{~kg}$ & $1.68 \times 10^{12}$ & {$[12]$} & $5.54 \times 10^{10}$ & $5.04 \times 10^{10}$ \\
Standard coal & $2.74 \times 10^{9} \mathrm{~J}$ & $2.51 \times 10^{9} \mathrm{~J}$ & $8.77 \times 10^{4}$ & {$[53]$} & $2.41 \times 10^{14}$ & $2.21 \times 10^{14}$ \\
Labor and service & $¥ 25.68$ & $¥ 25.68$ & $1.06 \times 10^{11}$ & {$[33]$} & $2.72 \times 10^{12}$ & $2.72 \times 10^{12}$ \\
Electricity & $3.168 \times 10^{8} \mathrm{~J}$ & $3.168 \times 10^{8} \mathrm{~J}$ & $4.5 \times 10^{5}$ & {$[54]$} & $1.43 \times 10^{14}$ & $1.43 \times 10^{14}$ \\
\hline
\end{tabular}

The energy calculations of standard coal: $20,900 \times 131 \times 1000=2.74 \times 10^{9} \mathrm{~J}$ (wet material); $20,900 \times 120 \times 1000=2.51 \times 10^{9} \mathrm{~J}($ dry material). 
Table 18. Emergy calculation of the cement products based on the total resources.

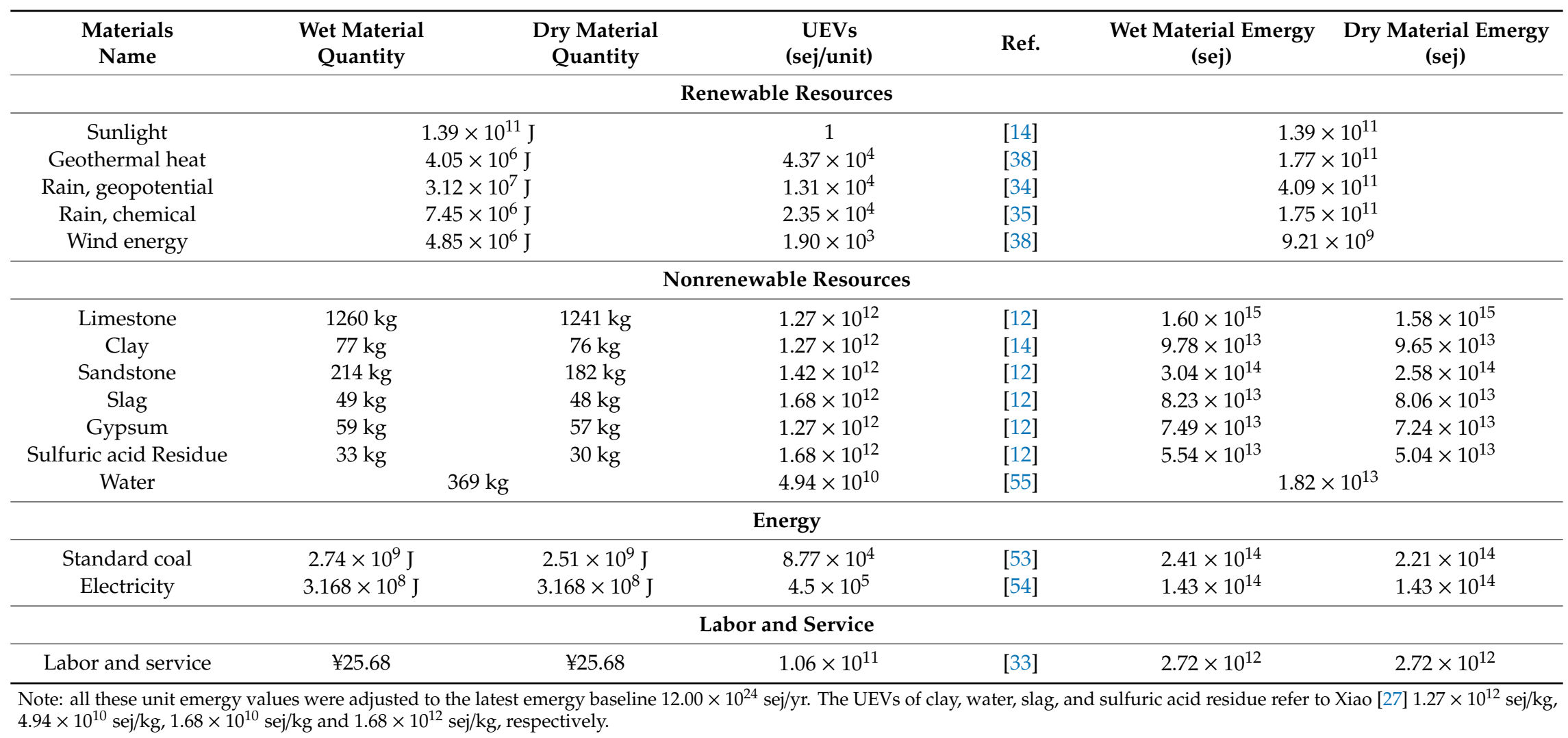


Table 19. Emergy analysis table of cement manufacturing in China.

\begin{tabular}{|c|c|c|c|c|c|c|}
\hline Item & $\begin{array}{c}\text { Wet Material Emergy } \\
\text { (sej) }\end{array}$ & $\begin{array}{c}\text { Dry Material Emergy } \\
\text { (sej) }\end{array}$ & $\begin{array}{c}\text { Total Emergy of Wet } \\
\text { Material }\end{array}$ & $\begin{array}{c}\text { Total Emergy of Dry } \\
\text { Material }\end{array}$ & $\begin{array}{l}\text { Wet Material } \\
\text { Proportion (\%) }\end{array}$ & $\begin{array}{c}\text { Dry Material } \\
\text { Proportion (\%) }\end{array}$ \\
\hline \multicolumn{5}{|c|}{ Renewable Resources } & \multirow[t]{2}{*}{$0.04 \%$} & \multirow[t]{3}{*}{$0.04 \%$} \\
\hline Sunlight & \multicolumn{2}{|c|}{$1.39 \times 10^{11}$} & \multirow{5}{*}{\multicolumn{2}{|c|}{$9.09 \times 10^{11}$ sej }} & & \\
\hline Geothermal heat & \multicolumn{2}{|c|}{$1.77 \times 10^{11}$} & & & \multirow{4}{*}{$0.04 \%$} & \\
\hline Rain, geopotential & & & & & \multirow[t]{3}{*}{$0.04 \%$} \\
\hline Rain, chemical & $1.75 \times 10^{11}$ & & & & & \\
\hline Wind energy & \multicolumn{2}{|c|}{$9.21 \times 10^{9}$} & & & & \\
\hline Limestone & $1.60 \times 10^{15}$ & $1.58 \times 10^{15}$ & \multirow{6}{*}{$2.17 \times 10^{15}$ sej } & \multirow{6}{*}{$2.09 \times 10^{15}$ sej } & $62.56 \%$ & $64.29 \%$ \\
\hline Clay & $9.78 \times 10^{13}$ & $9.65 \times 10^{13}$ & & & $3.82 \%$ & $3.93 \%$ \\
\hline Sandstone & $3.04 \times 10^{14}$ & $2.58 \times 10^{14}$ & & & $11.89 \%$ & $10.5 \%$ \\
\hline Slag & $8.23 \times 10^{13}$ & $8.06 \times 10^{13}$ & & & $3.22 \%$ & $3.28 \%$ \\
\hline Gypsum & $7.49 \times 10^{13}$ & $7.24 \times 10^{13}$ & & & $2.93 \%$ & $2.95 \%$ \\
\hline Sulfuric acid residue & $5.54 \times 10^{13}$ & $5.04 \times 10^{13}$ & & & $2.17 \%$ & $2.05 \%$ \\
\hline \multicolumn{5}{|c|}{ Energy } & $15.01 \%$ & $14.81 \%$ \\
\hline \multicolumn{5}{|c|}{ Labor } & $0.11 \%$ & $0.11 \%$ \\
\hline Labor and service & $2.72 \times 10^{12}$ & $2.72 \times 10^{12}$ & \multicolumn{2}{|c|}{$2.72 \times 10^{12}$ sej } & $0.11 \%$ & $0.11 \%$ \\
\hline Total & - & - & $2.56 \times 10^{15}$ & $2.46 \times 10^{15}$ & $100 \%$ & $100 \%$ \\
\hline UEV & \multicolumn{6}{|c|}{$2.56 \times 10^{12} \mathrm{sej} / \mathrm{kg}$ for wet material; $2.46 \times 10^{12} \mathrm{sej} / \mathrm{kg}$ for dry material } \\
\hline
\end{tabular}




\subsection{Emergy Indicators}

All specific indicators have been listed in Table 20. According to the Table 20, the detailed analysis is shown below.

Table 20. All the indicators of the emergy assessment for cement manufacturing.

\begin{tabular}{ccccc}
\hline \multirow{2}{*}{ No. } & Items & Indicators & \multicolumn{2}{c}{ Calculated Results } \\
\cline { 4 - 5 } & & & Wet Material & Dry Material \\
\hline 1 & Renewability rate & R & $0.03 \%$ & $0.04 \%$ \\
2 & Non-renewability rate of local resource & $\mathrm{N} \%$ & $82.62 \%$ & $82.76 \%$ \\
3 & Environmental loading ratio & ELR & 2390 & 2300 \\
4 & Emergy yield rate & EYR & 15.7 & 15.8 \\
5 & Emergy sustainability index & ESI & 0.0066 & 0.0069 \\
\hline
\end{tabular}

(1) Renewability rate ( $\mathrm{R} \%)$ is $0.03 \%$ of wet material and $0.04 \%$ of dry material, which demonstrates the poor renewable energy input for the evaluated system.

(2) Non-renewability rate of local resource $(\mathrm{N} \%)$ reveals the ratio $(0.8262$ and 0.8276$)$ of wet material and dry material, and the result illustrates the excessive local resource input and has caused huge pressure on the local environment.

(3) Environmental loading ratios (ELR) are 2390 (wet material) and 2300 (dry material), which show the excessive pressure on the system and some measures should carefully considered to decrease the ELR.

(4) Emergy yield ratios (EYR) are 15.7 and 15.8, representing the competitive ability of the evaluated system. It needs to balance the relationship between the total emergy section and the purchased emergy for the sustainability of the evaluated cement manufacturing.

(5) Emergy sustainability index (ESI) are 0.0066 and 0.0069 . They express the poor comprehensive effect on the environment for the evaluated system, and the ESI of cement manufacturing has an unsustainable status in the long term.

\section{Conclusions}

This paper applies the quota method to calculate the UEV of a mainstream cement production line of $5000 \mathrm{t} / \mathrm{d}$ in China. Based on cement chemical composition, the ratio of each main component is calculated, including limestone, clay, sandstone, gypsum, sulfuric acid residue, coal, slag and water. Both wet and dry proportions are considered and calculated in this paper, which can be compared and analyzed to improve the accuracy of the cement manufacturing system. Taking a typical 5000 ton cement production line as an example, the cement manufacturing system was evaluated in order to obtain a sustainable degree and unit emergy value. Based on this study, the UEV of wet material cement is $2.56 \times 10^{12} \mathrm{sej} / \mathrm{kg}$ and dry material cement is $2.46 \times 10^{12} \mathrm{sej} / \mathrm{kg}$. The UEVs of cement manufacturing in China from this study are a significant improvement from the previous study [26-28] in two ways-(1) the calculation of the ratio of raw materials, i.e., the inclusion of sandstone and clay in addition to limestone, coal, and electricity, and (2) the different water contents of the ingredients, the two types of calculation of cement UEV was carried out, involving wet material and dry material.

Emergy indicators show that the renewability rates $(\mathrm{R} \%)$ are $0.03 \%$ and $0.04 \%$ for wet material and dry material; the non-renewability rates of local resources $(\mathrm{N} \%)$ are 0.8262 and 0.8276 for the wet material and dry material. $\mathrm{R} \%$ and $\mathrm{N} \%$ show that there is less renewable energy and a lot more non-renewable energy inputs, resulting in the extremely high ELR (2390 of wet material, 2300 of dry material) and the very low ESI (0.0066 of wet material, 0.0069 of dry material).

Author Contributions: Conceptualization, J.Z.; methodology, R.S.S. and J.Z.; validation, R.S.S. and C.P.; formal analysis, J.Z.; investigation, J.Z.; resources, J.Z.; data curation, J.Z.; writing-original draft preparation, J.Z.; writing-review and editing, R.S.S.; supervision, R.S.S. and C.P. All authors have read and agreed to the published version of the manuscript. 
Funding: The work described in this paper was supported by the Postgraduate Research \& Practice Innovation Program of Jiangsu Province (KYCX18_0104) and the Ministry of Science and Technology of the Peoples Republic of China (Key Projects of Technological Innovation for Green Livable Village, Grant No. 2019YFD1100805).

Conflicts of Interest: The authors declare no conflict of interest.

\section{Appendix A}

\section{A1. Cement Composition}

Chemical formula of standard Portland cement:

Taking the Portland cement clinker of P.O42.5 as an example (GB175-2007), the fluctuation range of each major oxide content is: $\mathrm{CaO}(62-67 \%) ; \mathrm{SiO}_{2}(20-24 \%) ; \mathrm{Al}_{2} \mathrm{O}_{3}(4-7 \%) ; \mathrm{Fe}_{2} \mathrm{O}_{3}(2.5-6 \%)$.

Four main mineral types of Portland cement clinker:

Usually, calcium oxide and silicon oxide are first reacted to produce the dicalcium silicate at high temperatures. Then, calcium oxide and dicalcium silicate can generate tricalcium silicate.

The reaction formula is as follows (GB175-2007):

$$
\begin{gathered}
2 \mathrm{CaO}+\mathrm{SiO}_{2}=2 \mathrm{CaO} \cdot \mathrm{SiO}_{2}\left(\mathrm{C}_{2} \mathrm{~S}\right) \\
2 \mathrm{CaO} \cdot \mathrm{SiO}_{2}+\mathrm{CaO}=3 \mathrm{CaO} \cdot \mathrm{SiO}_{2}\left(\mathrm{C}_{3} \mathrm{~S}\right)
\end{gathered}
$$

Four main mineral types: $3 \mathrm{CaO} \cdot \mathrm{SiO}_{2} \quad\left(\mathrm{C}_{3} \mathrm{~S}\right) ; 2 \mathrm{CaO} \cdot \mathrm{SiO}_{2} \quad\left(\mathrm{C}_{2} \mathrm{~S}\right) ; 3 \mathrm{CaO} \cdot \mathrm{Al}_{2} \mathrm{O}_{3} \quad(\mathrm{C} 3 \mathrm{~A})$; $4 \mathrm{CaO} \cdot \mathrm{Al}_{2} \mathrm{O}_{3} \cdot \mathrm{Fe}_{2} \mathrm{O}_{3}\left(\mathrm{C}_{4} \mathrm{AF}\right)$.

Units Used as followed in Table A1:

Table A1. Units used in this paper.

\begin{tabular}{ccc}
\hline No. & Unit & Meanings \\
\hline 1 & $\mathrm{Sej}$ & Solar emjoules \\
2 & $\mathrm{sej} / \mathrm{yr}$ & Average annual emergy \\
3 & $\mathrm{~m}^{2}$ & Cement plant area \\
4 & $\mathrm{~J} / \mathrm{m}^{2} / \mathrm{yr}$ & Annual average energy per unit area \\
5 & $\mathrm{~J} / \mathrm{yr}$ & Annual mean energy \\
6 & $\mathrm{~m} / \mathrm{yr}$ & Average annual rainfall \\
7 & $\mathrm{sej} / \mathrm{j}$ & Unit emergy value \\
8 & $\mathrm{~kg} / \mathrm{m}^{3}$ & Density unit \\
9 & $\mathrm{~J} / \mathrm{kg}$ & Water Gibbs free energy unit \\
10 & $\mathrm{~m} / \mathrm{s}$ & Wind velocity unit \\
11 & $\mathrm{Kj} / \mathrm{Kg}-\mathrm{cl}$ & Energy consumed per kilogram of clinker \\
12 & $\mathrm{~g} / \mathrm{g}-\mathrm{cl}$ & Energy consumed per gram of clinker \\
13 & $\mathrm{KJ} / \mathrm{Kg}$ & Energy of 1 kg substance \\
14 & $\mathrm{t} / \mathrm{day}$ & Daily production of cement \\
15 & $\mathrm{t} / \mathrm{a}$ & The cement produced every year \\
16 & $\mathrm{t} / \mathrm{h}$ & Hourly cement output \\
16 & $\mathrm{t} /(n \cdot \mathrm{h})$ & Production of selected kiln \\
17 & $\mathrm{CNY} / \mathrm{t}$ & RMB per ton of cement \\
18 & $\mathrm{kWh} / \mathrm{t}$ & Electricity consumption per ton of cement \\
19 & $\mathrm{sej} / \mathrm{kg}$ & Emergy value per kilogram \\
\hline
\end{tabular}

\section{References}

1. Raposo, C.; Rodrigues, F.; Rodrigues, H. BIM-based LCA assessment of seismic strengthening solutions reinforced concrete precast industrial buildings. Innov. Infrastruct. Solut. 2019, 4, 51. [CrossRef]

2. Saade, M.R.M.; Guest, G.; Amor, B. Comparative whole building LCAs: How far are our expectations from the documented evidence? Build. Environ. 2020, 167, 106449. [CrossRef] 
3. Kamali, M.; Hewage, K.; Sadiq, R. Conventional versus modular construction methods: A comparative cradle-to-gate LCA for residential buildings. Energy Build. 2019, 204, 109479. [CrossRef]

4. Zhang, Y.; Yan, D.; Hu, S.; Guo, S. Modelling of energy consumption and carbon emission from the building construction sector in China, a process-based LCA approach. Energy Policy 2019, 134, 110949. [CrossRef]

5. Morales, M.; Moraga, G.; Kirchheim, A.P.; Passuello, A. Regionalized inventory data in LCA of public housing: A comparison between two conventional typologies in southern Brazil. J. Clean. Prod. 2019, 238, 117869. [CrossRef]

6. Shah, S.M.; Liu, G.; Yang, Q.; Wang, X.; Casazza, M.; Agostinho, F.; Lombardi, G.V.; Giannetti, B.F. Emergy-based valuation of agriculture ecosystem services and dis-services. J. Clean. Prod. 2019, 239, 118019. [CrossRef]

7. Pan, H.; Zhuang, M.; Geng, Y.; Wu, F.; Dong, H. Emergy-based ecological footprint analysis for a mega-city: The dynamic changes of Shanghai. J. Clean. Prod. 2019, 210, 552-562. [CrossRef]

8. Srinivasan, R.S.; Braham, W.W.; Campbell, D.E.; Curcija, C.D. Re(De)fining Net Zero Energy: Renewable Emergy Balance in environmental building design. Build. Environ. 2012, 47, 300-315. [CrossRef]

9. Shen, J.; Zhang, X.; Lv, Y.; Yang, X.; Wu, J.; Lin, L.; Zhang, Y. An improved emergy evaluation of the environmental sustainability of China's steel production from 2005 to 2015. Ecol. Indic. 2019, 103, 55-69. [CrossRef]

10. Wu, Z.; Di, D.; Wang, H.; Wu, M.; He, C. Analysis and emergy assessment of the eco-environmental benefits of rivers. Ecol. Indic. 2019, 106, 105472. [CrossRef]

11. Srinivasan, R.S.; Ingwersen, W.; Trucco, C.; Ries, R.; Campbell, D. Comparison of energy-based indicators used in life cycle assessment tools for buildings. Build. Environ. 2014, 79, 138-151. [CrossRef]

12. Brown, M.T.; Buranakarn, V. Emergy indices and ratios for sustainable material cycles and recycle options. Resour. Conserv. Recycl. 2003, 38, 1-22. [CrossRef]

13. Fan, Y.P.; Qiao, Q.; Fang, L.; Yao, Y. Emergy analysis on industrial symbiosis of an industrial park-a case study of Hefei economic and technological development area. J. Clean. Prod. 2017, 141, 791-798. [CrossRef]

14. Odum, H.T. Environmental Accounting Emergy and Environmental Decision Making; Wiley: West New York, NJ, USA, 1996.

15. Brown, M.; Ulgiati, S. Emergy measures of carrying capacity to evaluate economic investment. Popul. Environ. 2001, 22, 471-501. [CrossRef]

16. Liu, Z.; Geng, Y.; Wang, H.; Sun, L.; Ma, Z.; Tian, X.; Yu, X. Emergy-based comparative analysis of energy intensity in different industrial systems. Environ. Sci. Pollut. Res. 2015, 22, 18687-18698. [CrossRef] [PubMed]

17. Srinivasan, R.S.; Campbell, D.E.; Wang, W. Renewable Substitutability Index: Maximizing Renewable Resource Use in Buildings. Buildings 2015, 5, 581-596. [CrossRef]

18. Yi, H.; Srinivasan, R.S.; Braham, W.W. An integrated energyeemergy approach to building form optimization: Use of EnergyPlus, emergy analysis and Taguchi-regression method. Build. Environ. 2015, 84, 89-104. [CrossRef]

19. Yi, H.; Srinivasan, R.S.; Braham, W.W.; Tilley, D.R. An ecological understanding of net-zero energy building: Evaluation of sustainability based on emergy theory. J. Clean. Prod. 2017, 143, 654-671. [CrossRef]

20. Yi, H.; Braham, W.W.; Tilley, D.R.; Srinivasan, R. A metabolic network approach to building performance: Information building modeling and simulation of biological indicators. J. Clean. Prod. 2017, 165, 1133-1162. [CrossRef]

21. Yi, H.; Brahamb, W.W.; Tilley, D.R.; Srinivasan, R. Measuring ecological characteristics of environmental building performance: Suggestion of an information-network model and indices to quantify complexity, power, and sustainability of energetic organization. Ecol. Indic. 2017, 83, 201-217. [CrossRef]

22. Wang, Q.; Ma, Z.; Yuan, X.; Wang, J.; Mu, Z.; Zuo, J.; Zhang, J.; Hong, J.; Wang, S. Is cement pavement more sustainable than permeable brick pavement. A case study for Jinan, China. J. Clean. Prod. 2019, 226, 306-315. [CrossRef]

23. Li, D.; Zhu, J.; Hui, E.C.M.; Leung, B.Y.P.; Li, Q. An emergy analysis-based methodology for eco-efficiency evaluation of building Manufacturing. Ecol. Indic. 2011, 11, 1419-1425. [CrossRef]

24. National Bureau of Statistics of China. China Statistical Yearbook 2019. 2019. Available online: http://www.stats.gov.cn/tjsj/ndsj/2015/indexch.htm (accessed on 16 September 2019). (In Chinese) 
25. Ministry of Environmental Protection of People's Republic of China. 2015. Available online: http://www.mee.gov.cn/hjzl/ (accessed on 1 January 2020). (In Chinese)

26. Chen, W.; Liu, W.; Geng, Y.; Ohnishi, S.; Sun, L.; Han, W.; Tian, X. Life cycle based emergy analysis on China's cement production. J. Clean. Prod. 2016, 131, 272-279. [CrossRef]

27. Zhang, X.; Shen, J.; Wang, Y.; Qi, Y.; Liao, W.; Shui, W.; Li, L.; Qi, H.; Yu, X. An environmental sustainability assessment of China's cement industry based on emergy. Ecol. Indic. 2017, 72, 452-458. [CrossRef]

28. Song, D.; Chen, B. Sustainability evaluation of a typical cement production chain in China-An emergy perspective. Energy Procedia 2016, 104, 98-103. [CrossRef]

29. Brown, M.T.; Ulgiati, S. Assessing the global environmental sources driving the geo-biosphere: A revised emergy baseline. Ecol. Model. 2016, 339, 126-132. [CrossRef]

30. Lu, Y.M.; Yue, T.X.; Chen, C.F.; Fan, Z.M.; Wang, Q.M. Solar radiation modeling based on stepwise regression analysis in China. J. Remote Sens. 2010, 14, 852-864.

31. Anhui Conch Cement Company Limited. 2018 Annual Report; Anhui Conch Cement Company Limited: Wuhu, China, 2018; p. 22.

32. Gao, G.; Chen, D.L.; Xu, C.Y.; Simelton, E. Trend of estimated actual evapotranspiration over China during 1960-2002. J. Geophys. Res. 2007, 112, D11120. [CrossRef]

33. Lou, B.; Ulgiati, S. Identifying the environmental support and constraints to the Chinese economic growth-an application of the emergy accounting method. Energy Policy 2013, 55, 217-233. [CrossRef]

34. Campbell, D.; Andrew, O. Environmental Accounting Using Emergy: Evaluation of Minnesota; EPA/600/R-09/002; US Environmental Protection Agency: Narragansett, RI, USA, 2009.

35. Lu, H.; Campbell, D.E.; Chen, J.; Qin, P.; Hai, R. Conservation and economic vitality of nature reserves: An emergy evaluation of the yancheng biosphere reserve. Biol. Conserv. 2007, 139, 415-438. [CrossRef]

36. Miller, B.I. A Study of the Filling of Hurricane Donna over Land (2000). In Monthly Weather Review; U.S. Department of Agriculture: Washington, DC, USA, 1964; Volume 92, pp. 389-406.

37. Kraus, E.B. Atmosphere-Ocean Interaction. Oxford Monographs on Meteorology; U.K. Clarendon Press: Oxford, UK, 1972; p. 275.

38. Brown, M.T.; Bardi, E. Handbook of Emergy Evaluation: A Compendium of Data for Emergy Computation in a Series of Folios, Folio. \#3; Center for Environmental Policy, University of Florida: Gainesville, FL, USA, 2001.

39. National Standardization Administration. General Portland Cement Standard, GB175; National Standardization Administration: Beijing, China, 2007.

40. National Standardization Administration. Chemical Analysis Method of Limestone and Dolomite, GBT_3286.2; National Standardization Administration: Beijing, China, 2012.

41. National Standardization Administration. National Standard for Bauxite Ore, GB 24483; National Standardization Administration: Beijing, China, 2009.

42. National Standardization Administration. Siliceous Sandstone Standard, GBW03112; National Standardization Administration: Beijing, China, 1998.

43. National Standardization Administration. Industrial Sulfuric Acid, GBT 534; National Standardization Administration: Beijing, China, 2014.

44. National Standardization Administration. Industrial Analysis Method of Coal, GB/T212; National Standardization Administration: Beijing, China, 2008.

45. National Standardization Administration. Chemical Analysis Method of Gypsum, GB5484; National Standardization Administration: Beijing, China, 2000.

46. National Standardization Administration. Blast Furnace Slag Powder in Cement and Concrete, GB/T/18046; National Standardization Administration: Beijing, China, 2008.

47. Wei, S. Cement Technology (Rearrangement Version); Wuhan University of Technology Press: Wuhan, China, 2010.

48. National Standardization Administration. Calculation Method of Heat Balance, Thermal Efficiency and Comprehensive Energy Consumption of Cement Rotary Kiln, JC/T730-2007; National Standardization Administration: Beijing, China, 2020.

49. De Quan, C. Principle and Application of New Dry Process Cement Technology; China Building Materials Industry Press: Beijing, China, 2004.

50. National Standardization Administration. Fly Ash Used in Cement and Concrete, GB/T 1596; National Standardization Administration: Beijing, China, 2017. 
51. National Standardization Administration. General Rules for Comprehensive Energy Consumption Calculation, GBT2589; National Standardization Administration: Beijing, China, 2008.

52. National Standardization Administration. Cement Unit Product Energy Consumption Limit and Calculation Method, DB33/ 645; National Standardization Administration: Beijing, China, 2007.

53. Brown, M.T.; Protano, G.; Ulgiati, S. Assessing geobiosphere work of generating global reserves of coal, crude oil, and natural gas. Ecol. Model. 2011, 222, 879-887. [CrossRef]

54. Brown, M.T.; Raugei, M.; Ulgiati, S. On boundaries and 'investments' in emergy synthesis and LCA: A case study on thermal vs. photovoltaic electricity. Ecol. Indic. 2012, 15, 227-235. [CrossRef]

55. Buenfil, A.A. Emergy Evaluation of Water. Ph.D. Thesis, University of Florida, Gainesville, FL, USA, 2001.

(C) 2020 by the authors. Licensee MDPI, Basel, Switzerland. This article is an open access article distributed under the terms and conditions of the Creative Commons Attribution (CC BY) license (http://creativecommons.org/licenses/by/4.0/). 